\title{
LEVINAS, SOCIAL VULNERABILITY, AND THE LOGIC OF SOUTH AFRICAN RACISM
}

\begin{abstract}
The philosopher Emmanuel Levinas was at the forefront of the promotion of the idea of vulnerability in philosophy. For Levinas, my primary vulnerability concerns not my pain, but my pain at the other's pain. Vulnerablity also has an ambiguous character in so far as it is not easily separated from my self-absorption in enjoyment. In this paper I show how Levinas's account can illuminate the way that the idea of vulnerability sometimes operates within racist societies to maintain existing divisions. In particular I focus on the Carnegie Commission's 1932 study The Poor White Problem in South Africa where concern for the vulnerability of poor whites concealed a tendency to naturalize the vulnerability of South African Blacks.
\end{abstract}

Keywords: Carnegie commission, poor whites, racism, vulnerability, Emmanuel Levinas, South Africa.

\section{THE QUEST FOR INVULNERABILITY}

The concept of social vulnerability was introduced more than twenty years ago to isolate vulnerabilities created by society from natural or biophysical vulnerabilities. It was intended to highlight the way vulnerability is distributed unevenly and accrues to the marginalized, especially if they are already discounted as a result of racialization (Cutter, Boruff and Shirley 2003: 243; see Honkasalo in the introduction of this special issue). It has become one of the preferred categories employed by social scientists in their efforts to highlight the risks, existing and potential, to which both individuals and groups are exposed. The initial source of the risk may arise from nature, as well as from the actions and the indifference of other people. In the case of the vulnerabilities created by, for example, Hurricane Katrina, the source of the risks was a mixture of all three (Wailoo, O'Neill and Dow 2010: 193). From this perspective the most vulnerable are those who, when faced with such risks, have the least resources, economic or social, on which they can rely. They tend therefore to be the poor, migrants, the marginalized, the very young, the very old, and pregnant or nursing women. But because such people tend to be the most invisible, most readily forgotten, members of their societies, it can also happen that the attention they deserve is drawn away from them toward others, who are closer to the dominant members of society and who are for that reason given prominence. Social scientists thus often perform valuable work when they help to render more visible those who tend to be invisible to 
the privileged. And yet at times these same social scientists use the language of vulnerability to take attention away from the marginalized. In racist societies there is a tendency for privileged members of the dominant race to be more concerned with those with whom they share a racial identity, however little else they might have in common.

Racism preys on the socially vulnerable, as does sexism. Both racism and sexism conspire to make the already vulnerable more vulnerable by taking away the protections that most members of society enjoy. We see it in the way the police target those who cannot afford a competent lawyer to challenge any misuse of power that might have taken place. We see it also in the way refugees and immigrants, especially undocumented immigrants, are treated; they too lack legal protections. Nevertheless, privileged groups sometimes appropriate the language of vulnerability for themselves. Judith Butler gives the example of white people who claim that they are 'a 'vulnerable' population' in situations where they sense that they are losing their status as a majority (Butler 2016: 23). We see it also when the inhabitants of suburbia and postsuburbia in the United States announce their own vulnerability, even though their privileged life-styles are highly dependent on people who are more vulnerable than they are. In this essay I will take another example of the intersection of vulnerability and racism in an attempt to expose the intricate logic that pertains when race, gender, and class intersect. I will focus on the way the Carnegie Commission in 1932 turned its back on the poor black Africans, the Bantu or 'natives', to use the language of the Report which I will largely follow (Grosskopf 1932: 1). It focused almost exclusively on those who were called at the time 'poor whites'. This phrase was already considered derogatory in the United States in the late nineteenth century, which was where and when it seems to have originated (Gillmore 1864:115). In the South African context it referred predominantly, but not exclusively, to Afrikaans-speaking descendants of mainly Dutch, French, and German extraction (Wilcocks 1932: 1). They were mainly from families who had been on the land for generations and had failed to adapt to changing conditions. I shall present these findings within a philosophical context drawn largely from the work of Emmanuel Levinas thereby challenging the often repeated claim that his philosophy lacks the resources to contribute to the discussion of politics.

During the late 1970's, the term 'vulnerability' was already being used by philosophers to address a very different set of questions from these. One of the foremost of these philosophical questions is whether vulnerability is something entirely negative from which we must protect ourselves. Our answer to that question cannot be easily separated from our practical projects. If vulnerability is entirely negative, it would be reasonable to pursue the maximum amount of self-protection to the point where we begin to feel invulnerable. Do we protect the parts of our town that borders the river by building flood defences at the river's edge, even if that means that, when the rain comes, the city downstream will now be the one that suffers? Do we understand our expenditure on security to have been successful if it motivates the terrorists to target our neighbours simply because they chose not to build such elaborate defences? In these ways our quest for invulnerability would have contributed to the creation of a world which enhances our competition with others to the point of rendering them more vulnerable. The quest for invulnerability can have the effect of exacerbating already existing vulnerabilities.

In the face of these kinds of considerations an alternative perspective has developed 
based on the possibility of acknowledging vulnerability as something that is ultimately positive, something that speaks to our best qualities. Feminist philosophers especially have sought to reframe vulnerability in such a way that 'the spectre of violence no longer dominates' (Murphy 2012: 96). In the course of doing so they have raised concerns about the tendency to reduce vulnerability to 'an essentially negative state tantamount to harm', whereas in its ambivalence as neither inherently positive or inherently negative it can also be said to enable us and not just to limit us (Gilson 2011: 310). One prominent feature of the feminist accounts that is especially marked in the work of Judith Butler is that vulnerability is understood as relational (Drichel 2013: 15-18). This recognizes the way that, even when the vulnerable are physically isolated, they are not totally turned in on themselves, but can still easily be moved by the suffering of others. The idea that human beings are relational represents a fundamental challenge to the widespread tendency within modern liberal philosophy to abstract the human subject from the society in which it finds itself. It is a tendency that is continued when the phrase 'the vulnerable' is used as a blanket term. Vulnerability must be thought of concretely. For that reason I will develop an account of the operation of institutional racism and attempts to legitimate it in the specific context of The Poor White Problem in South Africa: Report of the Carnegie Commission. Only after doing so will I turn to the account Emmanuel Levinas gave of vulnerability, an account on which some of the authors I have referenced above drew heavily. My claim is that one needs an account of vulnerability as rich in ambiguity as the one that Levinas offers in order to illuminate sufficiently the complexity of concrete political situations.

\section{THE VULNERABILITY OF POOR WHITES IN SOUTH AFRICA}

The Poor White Problem in South Africa was published in 1932 in six parts divided into five volumes (Grosskopf 1932; Wilcocks 1932; Malherbe 1932; Murray 1932; Albertyn 1932; Rothmann 1932). Each of the five volumes was devoted to a different aspect of the problem from economics, psychology, and education to health, society, and mothers and daughters. Contemporaries praised the report for its spirit of strict scientific research and the international character of its approach (Anonymous 1933: 605). It has also been seen in retrospect as paving the way to apartheid not least in so far as it sought to promote greater separation between the two races on the grounds that 'the color line' was under threat both through social and sexual intercourse (Wilcocks 1932: 63).

So far as I can see the word vulnerability is not used in any of these five volumes, but an African American scholar, Tiffany WilloughbyHerard, in 2015 published Waste of a White Skin: The Carnegie Corporation and the Racial Logic of White Vulnerability which viewed the report through the lens of this concept. This wideranging book has been criticized because its use of the terms 'blacks' and 'whites' as binary opposites flattens 'the complex realities of South African racial and ethnic relations and identities' and forces them into a model more familiar to North American readers (Teppo 2016: 645). However, in spite of such concerns, there is no denying the importance of the questions she raises in the course of her analysis. She asks: 'What role did the study of abject whiteness play in the making of both grand apartheid and the social science that found it to be an appropriate accommodative social structure for regulating the impact of laws and policies enforcing racial difference?' (Willoughby-Herard 2015: 
$226 \mathrm{n} 10)$. In response, by highlighting the mechanisms by which 'whiteness that surfaces in the abject station usually understood to be the home of black people', she investigates 'the cultural work done by poor whiteness' (Willoughby-Herard 2015: 81). One should also remember that for many South Africans in this period racial differences were understood more in terms of culture than biology (Dubow 1995: 278)

Willoughby-Herard presents Waste of a White Skin as a corrective to the one-sided characterization of so-called white privilege by highlighting another neglected aspect of whiteness, its misery (Willoughby-Herard 2015: 128. See also 154). Her account seeks to show 'how white selfhood faces its own internalized racism, slave past, and self-hatred' (Willoughby-Herard 2015:81). So whereas many scholars who focus on Whiteness have imposed a certain homogeneity on all whites, she recognized the divisions within that category as they played out in The Poor White Problem in South Africa. The report, while being genuinely concerned with the suffering of the poor whites, stressed their differences from other more privileged Europeans as the whites were often called. The various authors of the Report were well aware that the incapacity of the poor whites to adapt to a rapidly changing world contradicted the premise on which South Africa was being built, the assumption of white racial superiority. It is this inflammatory combination that she calls the racial logic of white vulnerability' (Willoughby-Herard 2015: 81). Although Willoughby-Herard does not engage in a close reading of any part of The Poor White Problem in South Africa, by examining the Commission's 'Joint Findings and Recommendations' that was reprinted at the beginning of each of the five volumes and by supplementing this examination with references to the materials on which it was based, it is possible to develop a more detailed account of the racial logic that she identifies (Carnegie Commission 1932).

The 'Joint Findings and Recommendations' openly acknowledged that the very existence of poor whites whose conditions were becoming ever closer to those of the black population threatened the continued existence of South Africa in its current state: 'The term 'poor white' could not have come into usage except in a country inhabited by an inferior non-European population as well as by Europeans. The term 'poor white' itself implies that traditionally the European inhabitants have a higher standard of living' (Carnegie Commission 1932: xviii-xix). The conjunction of whiteness and poverty was 'felt to be something more or less exceptional' (Grosskopf 1923:17), but as the numbers of poor whites grew and their condition worsened it no longer seemed exceptional. Not only were some Europeans becoming wealthier, but some natives were improving their lot too with the result that the miseries of the poor whites were more striking: 'An increase of the average welfare of the Europeans (especially if accompanied by an improvement of the standard of living among a part of the non-European races) is sufficient to make the position of the less prosperous Europeans appear relatively unfavourable' (Carnegie Commission 1932: xix).

However, to the extent that economic forces were bringing poor whites into closer proximity with non-Europeans, there were social and psychological consequences that in the eyes of the Carnegie Commission constituted a second, ultimately more serious, problem. The 'poor whites' were not simply 'the white poor' (Wilcocks 1932: 80): 'longcontinued contact with inferior coloured races' had 'deleterious social effects on the Europeans', even if it was still relatively rare for them to be 
'going kaffir' (Carnegie Commission 1932: xix). The Commissioners were trying to conceal what was staring them in the face. They refused to say that the natives had become more 'civilized', but they acknowledged that they had 'acquired civilized needs' (Carnegie Commission 1932: xix). Instead, they highlighted the dangers of cultural contact. The poor whites might be clinging to 'primitive' farming methods (Carnegie Commission 1932: xi), but in the eyes of the Commission the natives were primitive. And, of course, the greatest fear, given the assumptions of the times, was the fear of miscegenation, even to the point where the Report highlighted some descendants of the poor whites who, while still poor, could no longer be considered white (Wilcocks 1932: 37). The Commissioners went to some lengths not to state their racial assumptions explicitly, but they emerged clearly enough from time to time. The change they sought in the poor whites themselves was an increase in 'racial self-respect' (Carnegie Commission 1932: xxix). The poor whites needed to understand that Europeans as a whole were supposed to be the "bearers of European civilization in South Africa' (Carnegie Commission 1932: xxv). But the real problem was understood to lie ultimately with the nonEuropeans.

The Carnegie Commission was heavily invested in seeing white poverty as radically distinct from black poverty. The first was considered anomalous, whereas the second was naturalized on the basis of the alleged racial inferiority of the Black population: white vulnerability framed black suffering as natural and reasonable, while simultaneously rendering Black racial resistance' unthinkable (Willoughby-Herard 2015: 9). The institutional framework of South Africa, its systemic racism, depended on the difference between the two kinds of poverty. Black poverty was not thought of as a deprivation, but as corresponding to the black's natural condition. Poor whites stood at the border separating whites from blacks and only if poor whites maintained their economic and social distance from the non-Europeans could the myth of White Supremacy be maintained. The more privileged Europeans were not wrong to consider the ideology on which they relied to be threatened by the failure of poor whites to adapt to changing circumstances. They were vulnerable, as was the system built around the idea that whites were allegedly the instruments of progress, the 'bearers of European civilization in South Africa' (Carnegie Commission 1932: xxv). In spite of evidence of chronic indolence among the poor whites already in the late eighteenth century (Murray 1932:5), it was the black population that was supposed to be inherently lazy, careless, and backward (Albertyn 1932: 39). The Report attributed a lack of racial self-respect to the poor whites, but the same time insisted that their reluctance to work at certain jobs was motivated by a reluctance to compete directly with the natives. Indeed it was suggested that it was because blacks were seen as lazy that poor whites would not do so-called 'kaffir work'. They would rather live off charity. Hence the 'policy of white labour', instituted in 1907 and extended in 1925 , by which that work was taken from the blacks and reassigned exclusively to the whites as a way of manipulating their perceptions of what work they should do (Wilcocks 1932: 76). This was just one of the ways by which the politicians had already, prior to the Report, sought to strengthen the barriers between the races while at the same time giving the poor whites economic help at the expense of the natives. The need for these protections showed that the poor whites could not compete directly with the natives in ways that maintained the country's racial ideology. In any case, this way 
of helping poor whites was directed less toward ameliorating their misery than to protecting the system.

The poor whites were and were not considered truly white. They were given a distinct identity in order to play the buffer role between the natives and the privileged whites, both of whom remained firmly in the background of the Commission's Report. Within its discourse blacks were deprived of vulnerability, poor whites embodied vulnerability, but the more privileged whites considered themselves the most vulnerable people because they had the most to lose. The vulnerability attributed to the poor whites was in this way inextricably tied to their racial ambiguity rather than simply the economic and social conditions under which they lived. If living conditions were what counted, then the discourse of vulnerability would have been centred on the native population. It was centred on the poor whites in large measure because the privileged whites depended on the colour line that the poor whites were failing to hold secure for their social position. There is no denying therefore that the Report, in so far as it reflected the feelings of the privileged whites, was self-serving. At the same time the outrage and sympathy they expressed in the face of the misery of the poor whites was genuine. Because at times both of these feelings were operable in such a way that even the people involved could not separate them, it seems appropriate to talk here in terms of a fundamental ambiguity

\section{THE CONDITION OF VULNERABILITY IS AMBIGUOUS}

The question now becomes how to approach philosophically this ambiguity that I have located in The Poor White Problem in South Africa. What makes this ambiguity possible?
How can it be theorized? What does it mean for our understanding of human subjectivity? In this final section I point to Levinas's account of vulnerability as a resource for exploring these questions.

Even before feminist philosophers took up vulnerability under that name as 'a condition of openness, openness to being affected and affecting in turn' (Gilson 2011:310), it was a theme in Levinas' work (Levinas 2003: 63). Levinas is best known as the philosopher of the face to face relation which he saw as providing the basis of ethics, understood as my responsibility for everything. It departs radically from a social science perspective in so far as its account of relationality is nonreciprocal and asymmetrical and so can only be presented from a first-person perspective (Levinas 1969: 53). On this account, any other human being who challenges me in my selfsufficiency and complacency is for me the Other; the Other takes me out of myself. In the face of the Other I do not have recourse to abstract principles or utilitarian calculations, but instead I find that prior to an act of will I have opened up my home and given away the food I needed for myself. Levinas insisted that in giving this account he was not preaching or telling us what we ought to do. Rather, his point was that in the context of a world in which war is pervasive, in which brief moments of peace are little more than the continuation of war by other means, and where in retrospect we can see the evil of the holocaust as the culmination of a tradition from which we find it hard to extract ourselves, there is nevertheless more to humanity than a history of violence. This at least is the way he presented his philosophy in what is still his best known book, Totality and Infinity from 1961. However, the noun vulnerability occurs there only once (Levinas 1969:256). The word became central to his thinking only 
when he changed his idiom and concentrated less on alterity and the face to face and more on proximity and on what we can say about the human subject given that the Other can challenge the subject's complacency. Levinas' focus on vulnerability is largely confined to a four-year period. It began with his 1970 essay, 'Without Identity', which can be understood in part as his response to the events in France of May 1968 (Levinas 2003: 58-69). The term was developed in earnest in the second and third chapters of his masterpiece Otherwise than Being published in 1974 (Levinas 1981: 48-81).

What is most striking about Levinas's conception of vulnerabilitu - 'prior vulnerability' as he called it (Levinas 2003: 64) - is that it is discovered, not in my own susceptibility to risk, but pre-eminently in my outrage at the other's being wounded (Levinas 2003: 63). Being mobilized to address the other's vulnerability is thus at the very heart of his conception of it. It is in the 'searing wound of cruelties and desolation endured by others' that Levinas finds the source of responsibility, an asymmetrical responsibility that extends to responsibility for the other's responsibility (Levinas 2003: 69, 64). To that extent my vulnerability is the site of relationality because its basis lies in the other's vulnerability, the other's pain. It is only to the extent that I accuse myself of 'the other's illness or pain' (Levinas 2003: 62) that the account found in Totality and Infinity begins to make sense, so that we can come to understand how in the face of the Other I find myself dispossessed and ready to give my life for another or for others.

By making the possibility of self-sacrifice central to his account of subjectivity, Levinas sought to break with the dominant tradition within Western philosophy according to which the subject is defined by concern for its selfpreservation. If one is from the outset a being concerned exclusively with one's own being, how is it possible to sacrifice one's being for another? Levinas attempts to give an account of the human subject that allows for both possibilities, being for oneself and being for others. Some commentators on Levinas go too far in this direction and treat our fundamental relationality as a being for the other. They turn being for oneself into a deficient mode of being for others. However, Levinas himself in no way tries to minimize the violence that we humans can and do direct against each other as constitutive of who we are. This complicates his account of relationality to the point where it does not conform to how the word is usually understood (Ziarek 2013: 69). It is in acknowledgement of this that he uses provocative phrases like 'relation without relation' (Levinas 1998: 80) in the sense of 'a relation and a non-relation' (Levinas 1998: 107). It might be objected that with these phrases Levinas is trying to have it both ways, but he would say that this is necessary if one is to account for a murderous world in which violence nevertheless can be transcended ethically. Levinas' point here can perhaps be best introduced by saying that although, in so far as I am for-the-other, I am in relation, at the same time I am not reducible to the relation in the way that theorists of fundamental relationality often seem to suppose. I am for-the-other but I exceed or escape the relation, as does the Other. That is to say, the Other is, like me, both interior and exterior to the relation (Levinas 1981: 115). Only in so far as the Other transcends the relation can the Other can challenge my selfsufficiency. Only in so far as I escape the relation can I assume responsibility for the Other or, alternatively, refuse this challenge to the point of wanting to kill him or her.

These are challenging ideas, not easily formulated outside Levinas' unique vocabulary, but one clear consequence is that his account of 
vulnerability is very different from what people ordinarily mean by the term. We have already seen that for him my vulnerability arises not only in the threat that others present to me, but also, and in a sense primarily, in the other's vulnerability. Because the Other transcends the relation there is a sense that in vulnerability as a relation, we cannot simply be understood as contemporaries of each other (Levinas 1998: 107). Your pain and suffering may be painful to me, but that does not mean I can say that I feel your pain. My initial response to the oppressed and those in need is not here a matter of understanding. Nor is he giving an account of empathy as traditionally understood. My response to your suffering may arise from what Levinas calls proximity, but it does not bring us closer together so that we become as one. My vulnerability to your vulnerability is not expressed in sharing your pain. It is expressed in a responsibility that is constitutive of my subjectivity. The responsibility is mine alone. To try to generalize it is to refuse it.

However, there is a further dimension to Levinas's account of vulnerability that is essential to understanding it in all of its complexity but which is often missed because it goes against a widespread image of his thought. Levinas insisted that although we can have the experience of pain interrupting enjoyment and tearing me away from myself (Levinas 1981:55), pain and enjoyment should not be understood as direct opposites. They come together in vulnerability which 'presupposes enjoyment differently than as its antithesis' (Levinas 1981: 64). Vulnerability is not only to be understood, following its etymology, as a wounding, but as a 'wounding in enjoyment' and it is in this way that it penetrates into the very heart of the subject, disturbing the complacency of a life lived solely on its own terms (Levinas 1981: 64).
Saidiya Hartman's brilliant account in Scenes of Subjection of the limits of empathic identification is helpful to understanding what Levinas means by the strange combination of wounding and enjoyment in the face of the Other's vulnerability. Her focus is on the way in which certain nineteenth-century abolitionists sought to promote opposition to slavery by cultivating empathy as a way of countering the cold indifference with which the suffering of the slaves was being met. Hartman points out that doing so amounted to 'exploiting the vulnerability of the captive body as a vessel for the uses, thoughts, and feelings of others' (Hartman 1997: 19). The captive body became 'an abstract and empty vessel vulnerable to the projection of others' feelings, ideas, desires, and values' (Hartman 1997: 21). The problem is that in the course of doing so the abolitionists can begin to feel more for themselves than 'for those whom this exercise in imagination presumably is designed to reach' (Hartman 1997: 19). In the end one is left uncertain whether the cold indifference has in fact been addressed or whether instead the impossibility of understanding the suffering of the enslaved has simply been affirmed. This is the ambivalent character of empathy that is all the more pronounced in this context because of the degree to which 'blacks were envisioned fundamentally as vehicles for white enjoyment' (Hartman 1997: 23). Indeed, there is the possibility of a certain callous enjoyment in the very process of empathic identification itself that arises both from the knowledge that I have overcome my indifference and the recognition that whatever it is that I am feeling, it is not what the Other feels.

This helps to explain why one should not reduce Levinas's description of vulnerability as outrage at the other's being wounded simply to the application of empathy, even while he 
is called upon to account for the ambivalence that he and Hartman identify. For him 'the condition of vulnerability' is ambiguity in so far as it arises from its inseparability from both self-preservation and enjoyment. So, for example, giving is ethical from a Levinasian perspective only when we are giving not from our surplus, but from what we need and enjoy. There must be some sacrifice involved. That is why he emphasizes that the gift of bread to the other is a gift of 'the bread from out of the mouth that tastes it' (Levinas 1981: 64). This highlights the way complacency and giving are to varying degrees intertwined at every instant. But there is ambiguity here too. What I regard as my generosity does not come only at a loss: it can help me feel good about myself. The gift is and is not self-serving. This is part of the same ambiguity Levinas found in vulnerability (Levinas 1981: 80).

If we are to talk, as Willoughby-Herard does, of white vulnerability in relation to the Carnegie Commission's Report, it should be in terms of this same ambiguity. The everyday sense of vulnerability does not suffice. On the one hand, there is the concern for the poor whites who are undeniably deserving of sympathy. Some of the stories found in the Report, especially in the section on mothers and daughters, are gut wrenching and clearly presented so as to promote empathic identification (Rothmann 1932). On the other hand, the Commission's concern for the poor whites seems to block any concern for the plight of the so-called natives. The natives appear in the Report simply in so far as they are a bad influence on the poor whites, thereby turning the poor white problem into a native problem leading to the idea that the solution to the poor white problem is the introduction of measures directed against the non-Europeans, who are in fact the most vulnerable but who are not recognised as such. And what lies behind these measures as they are proposed and implemented by the more privileged whites in South Africa is not only their concern for the poor whites but their concern for themselves. What they discover in the desolation of the poor whites is their own vulnerability because the poor whites stand between them and the collapse of the order on which all their privileges rely. It is impossible for them or us to say in each case the extent to which they are motivated by their outrage at the vulnerability of the poor whites and to what extent they are motivated by selfpreservation.

One might wonder, finally, whether the example of South African racism is not overdetermined because it is so extreme. But the same logic can be seen in current discussions in the United States around so-called 'rust belt politics' where more concern seems to be being shown for the white poor because it helps drive a wedge between them and African Americans or recent migrants. Indeed, it seems that some among the liberal elite have accepted this argument and have used it as a way of distracting attention from the inequalities produced by systemic racism. Here too the focus on the problems that face poor whites look to be emerging from an ethical concern that may be genuine, while at the same time harbouring a political agenda born of selfinterest. The problem is that in discussions of ethics and politics we tend to operate with simple dichotomies: rich and poor, love and hate, good and evil, black and white. Levinas is also often read through these dichotomies, but I have argued that, on his account, vulnerability is neither simply positive nor simply negative, but beyond both. ${ }^{1}$ 


\section{NOTES}

1 An earlier version of this paper was delivered on April 19, 2018 in Uppsala at the Vulnerabilities conference hosted by the Swedish Anthropological Association in conjunction with the Finnish Anthropological Society. The meeting came for me as the culmination of my visit to the Engaging Vulnerability initiative at Uppsala University. I would like to thank Mats Hyvönen, Sverker Finnström Sharon Rider, Annika Björnsdotter Teppo and especially Don Kulick for the generous hospitality they showed me during my stay with them.

\section{REFERENCES}

Albertyn, J. R. 1932. The Poor White and Society: The Poor White Problem in South Africa. Volume 5:1-16. Stellenbosch: Ecclesia.

Anonymous 1933. The Poor White Problem in South Africa. The Carnegie Commission Report. Round Table. The Commonwealth Journal of International Affairs 23 (91): 605-618.

https://doi.org/10.1080/00358533308450636.

Butler, Judith 2016. Rethinking Vulnerability in Resistance. In Judith Butler, Zeynep Gambetti, and Leticia Sabsay (eds). Vulnerability in Resistance. Durham: Duke University Press.

Carnegie Commission 1932. Joint Findings and Recommendations The Poor White Problem in South Africa. Stellenbosch: Ecclesia.

Cutter, Susan L., Bryan J. Boruff and W. Lynn Shirley 2003. Social Vulnerability to Environmental Hazards. Social Science Quarterly 84 (2): 242-261. https://dx.doi.org/10.1111/1540-6237.8402002.

Drichel, Simone 2013. Introduction: Reframing Vulnerability. SubStance 42 (3): 3-27.

Dubow, Saul 1995. Scientific Racism in Modern South Africa. Cambridge: Cambridge University Press.

Gillmore, J. R.1864. The 'Poor Whites' of the South. Harper's Magazine 28 (169): 115-124.

Gilson, Erinn 2011. Vulnerability, Ignorance, and Oppression. Hypatia 26 (2): 308-332.

https://dx.doi.org/10.1111/j.1527-2001.2010.01158.x.
Grosskopf, J. F. W. 1932. Rural Impoverishment and Rural Exodus. Stellenbosch: Ecclesia.

Hartman, Saidiya V. 1997. Scenes of Subjection: Terror, Slavery, and Self-making in Nineteenth-century America. Oxford: Oxford University Press.

Levinas, Emmanuel 1969. Totality and Infinity. Translated by Alphonso Lingis. Pittsburgh: Duquesne University Press.

Levinas, Emmanuel 1981. Otherwise than Being or Beyond Essence. Translated by Alphonso Lingis. The Hague: Martinus Nijhoff.

Levinas, Emmanuel 1998. Of God Who Comes to Mind. Translated by Bettina Bergo. Stanford: Stanford University Press.

Levinas, Emmanuel 2001. Existence and Existents. Translated by Alphonso Lingis. Pittsburgh: Duquesne University Press.

Levinas, Emmanuel 2003. Humanism of the Other. Translated by Nidra Poller. Urbana: University of Illinois Press.

Malherbe, E. G. 1932. Education and the Poor White. Stellenbosch: Ecclesia.

Murray, W. A. 1932. Health Factors in the Poor White Problem. Stellenbosch: Ecclesia.

Murphy, Ann 2012. Violence and the Philosophical Imaginary. Albany: State University of New York Press.

Rothmann, M. E. 1932. The Mothers and Daughters: Poor White Problem in South Africa. Volume 5: 147217. Stellenbosch: Ecclesia.

Teppo, Annika Björnsdotter 2016. Whiteness, Race and South Africa's Colonial Project. Journal of Southern African Studies 43 (3): 644-646.

https://dx.doi.org/10.1080/03057070.2017.1309847.

Wailoo, Keith, Karen M. O’Neill, and Jeffrey Dow 2010. Race, Vulnerability, and Recovery. In Wailoo, Keith, Karen M. O'Neill, Jeffrey Dow, and Roland Anglin (eds). Katrina's Imprint: Race and Vulnerability in America. Edited by. New Brunswick: Rutgers University Press.

Wilcocks, R. W. 1932. The Poor White. Psychological Report. Stellenbosch: Ecclesia. 
Willoughby-Herard, Tiffany 2015. Waste of a White Skin: The Carnegie Corporation and the Racial Logic of White Vulnerability. Oakland: University of California Press.

Ziarek, Ewa Plonowska 2013. Feminist Reflections on Vulnerability: Disrespect, Obligation, Action. SubStance 42 (3): 66-84.

\section{ROBERT BERNASCONI}

EDWIN ERLE SPARKS PROFESSOR OF

PHILOSOPHY AND AFRICAN AMERICAN STUDIES

THE PENNSYLVANIA STATE UNIVERSITY rlb43@psu.edu 